\title{
k-FGF protoncogene expression is associated with murine testicular teratogenesis, but is not involved during mouse testicular development
}

\author{
J.M. de Anta, M. Monzó, B. Peris and D. Ruano \\ Department of Morphological Sciences, Faculty of Medicine, University of Barcelona, Barcelona, Spain
}

Summary. The k-FGF gene, which belongs to the family of the fibroblast growth factor genes, is implicated in tumoral and developmental processes. It is expressed in embryonal carcinoma cells, in embryonic stem cells, during limb and tooth formation and in some germ cell tumors. However, the expression of this protooncogene during testicular development as well its relationship to spontaneous teratogenesis have not been determined. Here we investigate k-FGF expression during testicular development in mice, as well as in a spontaneous testicular teratoma (STT) and in the OTT6050 teratocarcinoma (TC) by Northern blotting, RT-PCR and in situ hybridization. Several data indicate that k-FGF gene contains downstream regulatory sequences which bind octamer factors. One of these transcription factors which binds to k-FGF enhancer is Oct-4. Although the $\mathrm{k}-\mathrm{FGF}$ gene is activated by Oct-4 in embryonal carcinoma and embryonic stem cells and Oct-4 is expressed in the germ cells of the embryo, our results indicate that there is no detectable k-FGF expression in mouse testicular germ cells at any stage of development. This indicates that Oct- 4 does not activate transcription of the k-FGF gene in mouse germ cells, and that k-FGF is not implicated during testicular development. We also show that there is a high k-FGF expression in the experimental OTT6050 TC, but only very low levels in a murine differentiated STT, suggesting that k-FGF activation may be responsible for the genesis and development of STT, behaving as a marker of malignancy in these neoplasms.

Key words: k-FGF, Fgf-4, Spontaneous testicular teratoma, Mouse testicular development, OTT6050 teratocarcinoma, RT-PCR, In situ hybridization

\section{Introduction}

The k-FGF gene, also known as $h s t-1 / \mathrm{HSTF} 1$ (Sakamoto et al., 1986; Yoshida et al., 1988a-c), KS3

Offprint requests to: Dr. Josep Maria de Anta, Department of Morphological Sciences, Faculty of Medicine, University of Barcelona, C/ Casanova 143, 08036 Barcelona, Spain
(Delli Bovi and Basilico, 1987) or FGF-4 (Hébert et al., 1990 ) is a member of the fibroblast growth factor (FGF) family of genes. This family includes nine members classified more or sequence comparisons than on functional equivalence (Burgess and Maciag, 1989; Tronick and Aaronson, 1995). FGFs are implicated in cell proliferation, cell differentiation, morphogenesis and neoplasia. They are mitogenic for cells derived from mesoderm and neuroectoderm lineages. The product of the $\mathrm{k}-\mathrm{FGF}$ gene is a secreted glycoprotein of $22-\mathrm{kD}$ that stimulates the proliferation of NIH 3T3 fibroblasts (Delli Bovi et al., 1987) as well as HUE vascular endothelial cells (Miyagawa et al., 1988; Yoshida et al., 1994), demonstrating a role for $\mathrm{k}-\mathrm{FGF}$ in angiogenesis. In addition, the role of k-FGF in development has been demonstrated in Xenopus laevis by its mesoderminducing capacity of ectodermal tissue explants (Paterno et al., 1989) as well in the mouse. In mice, k-FGF is expressed in peri-implantation embryos (Rappolee et al., 1994), is essential for postimplantation mouse development (Feldman et al., 1995), and also participates in myogenesis and in specific epithelialmesenchymal interactions during limb and tooth morphogenesis (Nisswander and Martin, 1992; Niswander et al., 1993, 1994; Vogel and Tickle, 1993; Jernvall et al., 1994). All these data suggest that FGFs in general, and particularly k-FGF, have different roles in normal development. On the other hand, k-FGF gene is implicated in the tumoral process. It was isolated after transfection of human stomach cancer DNA (Sakamoto et al., 1986) and from Kaposi sarcoma DNA (Delli Bovi et al., 1987) which contained DNA rearrangements upstream and downstream of the coding sequences.

Due to the fact that the proteins encoded in the oncogene and in the protoncogene are identical (Yoshida et al., 1987; Delli Bovi et al., 1988), the oncogenic activation of the $\mathrm{k}-\mathrm{FGF}$ gene must result from unregulated expression and not from the genesis of a mutated form. Transfection of its cDNA induces cell motility, and malignancy (Delli Bovi et al., 1988; McLeskey et al., 1993; Taylor et al., 1993). It is expressed in human testicular germ cell tumors (Schofield et al., 1991; Strohmeyer et al., 1991) and in teratocarcinoma stem cells (Velcich et al., 1989; 


\section{k-FGF expression in testicular development and teratogenesis}

Schofield et al., 1991). In addition, it is found amplified (Chikuba et al., 1995) and coamplified with the int-2 gene (Yoshida et al., 1988a-d) and the $b c l-1$ gene (Volling et al., 1993) in some human cancers, and there is an association between amplification, high k-FGF expression and metastatic phenotype in mouse mammary tumors (Murakami et al., 1990) and in an experimental system (Damen et al., 1991). Moreover, angiogenic properties of the k-FGF oncogene have also been determined, and its possible association with the metastatic phenotype (Brustle et al., 1992; Díaz-Flores et al., 1994).

An aspect that has not been studied is its expression during testicular development in mice. Testicular development involves cell migration, proliferation and differentiation processes. During embryogenesis, small amounts of primordial germ cells (PGC) are clustered around the hind gut of E7.5. They proliferate, move into the wall of the hind gut, leave the gut through the dorsal mesentery and travel around the dorsal aorta and the coelomic angles into the genital ridges. PGC reach genital ridges at 10.5-11.5 days postcoitum (p.c.), the place where the future gonad will be formed. Sexual differentiation starts at 12.5 days p.c.. In male embryos, the number of PGC increases steadily until days 14-16 p.c., as soon as the testis cords are formed (this depends on the strain of mice) and then are arrested in the $\mathrm{G}_{1}$ phase of the cell cycle (Kluin and de Rooij, 1981). During the postnatal period spermatogenesis starts. After birth, gonocytes proliferate and give rise to A spermatogonia (Vergouwen et al., 1991), then the numbers of stem cell spermatogonia and the production of differentiating spermatogonia increase almost twofold between day 13 and week 12 (Kluin et al., 1984). In male mice, meiotic division does not start until 9-10 days post partum (p.p.) and spermiogenesis approximately until 30 days $p . p$.

In addition to all these data, testicular tumors, particularly nonseminomas, express high levels of $\mathrm{k}$ FGF mRNA (Strohmeyer et al., 1991). Neither adult testis nor any somatic cell express k-FGF (Burgess and Maciag, 1989). It is also known that k-FGF expression in undifferentiated embryonal carcinoma (EC) and embryonic stem (ES) cells is controlled by an upstream NF-Y-binding site, and a downstream element residing in the third exon which functions as an enhancer (Curatola and Basilico, 1990; Sasaki et al., 1991; Hasan et al., 1994; Koda et al., 1994; Bryans et al., 1995). These regulatory elements include a consensus octamer sequence that is a target for positive regulation by Oct-4 (Schoorlemmer and Kruijer, 1991). Due to the fact that $\mathrm{k}-\mathrm{FGF}$ is positively regulated by Oct-4, that Oct-4 is expressed in PGC (Schöler et al., 1989; Schöler, 1991) and that $\mathrm{k}-\mathrm{FGF}$ is expressed in EC cells and ES (Yoshida et al., 1988b; Heath et al., 1989; Velcich et al., 1989; Hébert et al., 1990) and in germ cell testicular tumors, we decided to study k-FGF expression during testicular development in mice. We investigated k-FGF expression in developing gonads from mouse embryos, in mouse postnatal testis, in the experimental OTT6050 terato- carcinoma (TC) and in a spontaneous testicular teratoma (STT) by Northern blotting, RT-PCR and in situ hybridization.

\section{Materials and methods}

\section{Testis, tumor and embryo obtention}

Postnatal testis at different stages of development were obtained from $129 / \mathrm{Sv}$ male mice. $129 / \mathrm{sSv}$ isogenic mice were obtained from Prof. Jacob of the Pasteur Institute (Paris, France). Day of partum was designed as T0. T2, T5, T10, T18, T25 and T72 testis were dissected and extracted from the intraperitoneal cavity of male $129 / \mathrm{Sv}$ mice.

OTT6050 mouse TC used in these experiments was obtained by injecting subcutaneously $10^{5}$ embryoid bodies (EB) in PBS into $129 / \mathrm{Sv}$ isogenic mice, and dissecting the tumor after 2 weeks. OTT6050 TC was derived from $129 / \mathrm{Sv}$ mouse E6.5 grafted to a histocompatible host testis. The ascitic form of the tumor (EB) was obtained after several intraperitoneal passages of solid TC (Stevens, 1970). EB were kindly supplied by Prof. Jacob. A STT was obtained from an adult 129/Sv mouse left testis.

Embryos were obtained from pregnant $129 / \mathrm{Sv}$ isogenic mice. $129 / \mathrm{Sv}$ mice have been maintained in our laboratory since 1984. Noon of the day on which the copulating plug was observed was considered to be 0.5 days of gestation (E0.5). Embryos at early postimplantation stages (E7.5 to E9.5) were processed including decidua, E10.5 to E11.5 were dissected from the implantation site and processed including extraembryonic annexes and E12.5 to E14.5 were dissected from decidua and annexes. For Northern blot and RTPCR analysis, the head and the body were dissected (below the liver) in E13.5 to E14.5.

\section{Cell culture}

F9 embryonal carcinoma cell line was cultured in gelatin-coated petri dishes in Dulbecco's Modification of Eagle's Medium (DMEM) (Flow Lab.) containing 10\% fetal calf serum (FCS) (Serva) and 1\% L-Glutamine. Cells were cultured at $37^{\circ} \mathrm{C}$ in a $5 \% \mathrm{CO}_{2}$ atmosphere to confluence. They were disrupted in a solution containing $0.25 \%$ trypsin and $0.04 \%$ EDTA and washed in PBS.

\section{RNA and DNA isolation}

Total cellular RNA was isolated by the acid guanidinium thiocyanate-phenol-chloroform extraction method (Chomzynski and Sacchi, 1987).

DNA from F9 cells was isolated by the method described by Blin and Stafford (1976).

\section{Primer design}

For specific priming in RT-PCR analysis, two 20nt oligonucletide primers spanning the second intron of the 
mouse k-FGF gene (Brookes et al., 1989), RTKF2 5'TGGTGAGCATCTTCGGAGTG 5' and RTKF1 5' TTCATGGTAGGCGACACTCG 3' were designed and produced in a DNA synthesizer (Applied Biosystems).

\section{$R T-P C R$ reaction}

For the reverse transcriptase reaction, $100 \mathrm{ng}$ of RNA samples were heated at $95{ }^{\circ} \mathrm{C}$ for $10 \mathrm{~min}$, cooled on ice and cDNA synthesis was performed at $42{ }^{\circ} \mathrm{C}$ for $30 \mathrm{~min}$ in $50 \mathrm{mM} \mathrm{KCl}, 10 \mathrm{mM}$ Tris- $\mathrm{HCl} \mathrm{pH} 9.0,0.1 \%$ Triton X-100, $1.5 \mathrm{mM} \mathrm{MgCl} 2$ using $1 \mathrm{mM}$ dNTPs (Pharmacia), $20 \mathrm{U}$ RNasin (Promega), 100 pmoles downstream primer (RTKF1) and $10 \mathrm{U}$ AMV reverse transcriptase (Promega). Then the reaction mixture was heated at $95{ }^{\circ} \mathrm{C}$ for $10 \mathrm{~min}$, chilled on ice and 100 pmoles upstream primer (RTKF2) and 1 U AmpTaq DNA pol (Perkin Elmer Cetus) were added for a normal PCR reaction. The thermal profile used was $95{ }^{\circ} \mathrm{C}$ denaturation for $1 \mathrm{~min}$, annealing of primers at $68{ }^{\circ} \mathrm{C}$ for $1 \mathrm{~min}$ and extension of the primers at $72{ }^{\circ} \mathrm{C}$ for $1 \mathrm{~min}$. This cycle was repeated 22 times.

\section{Southern blotting}

One tenth of the RT-PCR reaction was fractioned in a $1.8 \%$ agarose TBE gel, stained with ethidium bromide, photographed, treated with $0.25 \mathrm{~N} \mathrm{HCl}, 1 \mathrm{M} \mathrm{NaCl} / 0.5 \mathrm{M}$ $\mathrm{NaOH}$, equilibrated in $0.5 \mathrm{M}$ Tris- $\mathrm{HCl} \mathrm{pH} 7.4 / 1.5 \mathrm{M} \mathrm{NaCl}$ and blotted to Genescreen membranes (Dupont) in $10 \mathrm{xSSC}$. DNA was immobilized by baking the membrane at $80{ }^{\circ} \mathrm{C}$. Hybridization was performed in $50 \%$ formamide, $6 x$ SSPE, $1 \%$ SDS, $50 \mu \mathrm{g} / \mathrm{ml}$ denatured salmon sperm DNA at $42{ }^{\circ} \mathrm{C}$ for 16 to $24 \mathrm{~h}$. A Avall 155 $\mathrm{pb}$ mouse genomic k-FGF fragment including $3 \mathrm{rd}$ coding exon and 2 nd intron sequences was used as a probe. This probe recognized k-FGF-specific genomic and RNA-amplified fragments, but not priming sequences. This was labelled to a specific activity of $2 \times 10^{6} \mathrm{cpm} / \mathrm{ml}$ using a random primer DNA Labeling kit (Boehringer Mannheim) and $\alpha^{32} \mathrm{P}-\mathrm{dCTP}$ (Amersham). After hybridization, filters were washed and exposed to XAR films (Kodak) at $-80^{\circ} \mathrm{C}$ using intensifying screens, and developed.

\section{RNA probes and Northern blotting}

A mouse 417 bp Hindll/Xbal fragment from pXMT2-1.58kFGF plasmid that included the 2nd exon and a part of intronic sequences, was subcloned in pBluescript II SK + (Stratagene) giving rise to pBSkfHX. pBSkfHX was linealized with Hindll and Xbal. $\alpha^{32}$ P-UTP and $\alpha^{32}$ S-UTP labelled single stranded antisense and sense k-FGF riboprobes were transcribed using T3 and T7 RNA pol respectively.

As a positive control, a $\alpha^{32} \mathrm{P}-\mathrm{UTP}$ labelled human $B$ actin cRNA was used as a probe. The human $B$-actin cDNA cloned in pGEM-4Z (Promega) was linealized with EcoRI and Hindlll before being transcribed using
T7 RNA pol and SP6 RNA pol to create antisense and sense single-stranded ridoprobes. Both were alkaline hydrolized to reduce probes to an average size of $400 \mathrm{nt}$.

For Northern blotting experiments, $25 \mu \mathrm{g}$ of total RNA were denatured in $50 \%$ formamide, $2.2 \mathrm{M}$ formaldehyde, $20 \mathrm{mM}$ MOPS $\mathrm{pH} 7.0,5 \mathrm{mM}$ sodium acetate, and $1 \mathrm{mM}$ EDTA. RNA samples were diluted in loading buffer containing $0.1 \%$ bromophenol blue and $10 \%$ glycerol and electrophoresed in $1 \%$ agaroseformaldehyde-MOPS gel. The gel was transferred onto Genescreen membranes (Dupont) in $10 \times \mathrm{SSC}$. Hybridization was performed in $50 \%$ formamide, $5 \mathrm{x}$ Denhardt's solution, 5xSSPE, $1 \%$ SDS, $200 \mu \mathrm{g} / \mathrm{ml}$ denatured, and fragmented salmon sperm DNA at $42{ }^{\circ} \mathrm{C}$ for 16 to $24 \mathrm{~h}$.

Riboprobes were used at a specific activity of $2 \times 10^{6}$ $\mathrm{cpm} / \mathrm{ml}$. Washes were made at high stringency conditions and autoradiography was performed as Southern blots. For B-actin hybridization, k-FGF riboprobe was removed from the filter by washing in $50 \%$ formamide, $6 \times \mathrm{SSPE}$ for $40 \mathrm{~min}$ at $65^{\circ} \mathrm{C}$.

\section{In situ hybridization}

Testis, tumors and embryos were fixed in $4 \%$ paraformaldehyde, $5 \mathrm{mM} \mathrm{MgCl} 2$ in PBS, dehydrated, embedded in paraffin wax and sectioned at $6 \mu \mathrm{m}$. In situ hybridization conditions were performed at high stringency conditions according to the method of Frohman et al. (1990). k-FGF and B-actin riboprobes were used at a specific activity of $10^{5} \mathrm{cpm} / \mu \mathrm{l}$. Slides were exposed to an autorradiographic emulsion (NTB2, Kodak) $1: 1$ diluted in $0.6 \mathrm{M}$ ammonium acetate at $4{ }^{\circ} \mathrm{C}$ in the dark between three to four weeks (k-FGF) or one week (human $B$-actin) before being developed and stained with hematoxylin-eosin.

\section{Results}

Northern blot analysis of KFGF mRNA in postnatal testis, OTT6050 TC, a 129/SV STT, F9 cells and embryos

It is known that murine gonocytes and testicular germ cells prepared from neonatal mice proliferation in vitro. Due to the fact that $\mathrm{k}-\mathrm{FGF} \mathrm{mRNA}$ is expressed in human and murine embryonal carcinoma cells, mouse embryonic stem cells and human testicular germ cell tumors, we investigated the expression of the k-FGF gene in postnatal testis at different days postpartum (T2, T5, T10, T14, T25 and T72) by Northern blotting. As shown in Fig. 1 there was no detectable expression in mouse testis at different ages of development.

We also analyzed k-FGF expression in a STT, in the OTT6050TC and in F9 cells. We were unable to detect any transcript (Fig. 1), even after exposing the $X$ ray film for several days in STT. In OTT6050 TC and in F9 cells we detected a transcript of $3.5 \mathrm{~kb}$, although the level of expression was several fold higher in F9 cells (Fig. 1). Finally, we could not detect any k-FGF 
36

\section{k-FGF expression in testicular development and teratogenesis}

\section{$\begin{array}{lllllllllllllllllll}1 & 2 & 3 & 4 & 5 & 6 & 7 & 8 & 9 & 10 & 11 & 12 & 13 & 14 & 15 & 16 & 17 & 18 & 19\end{array}$}
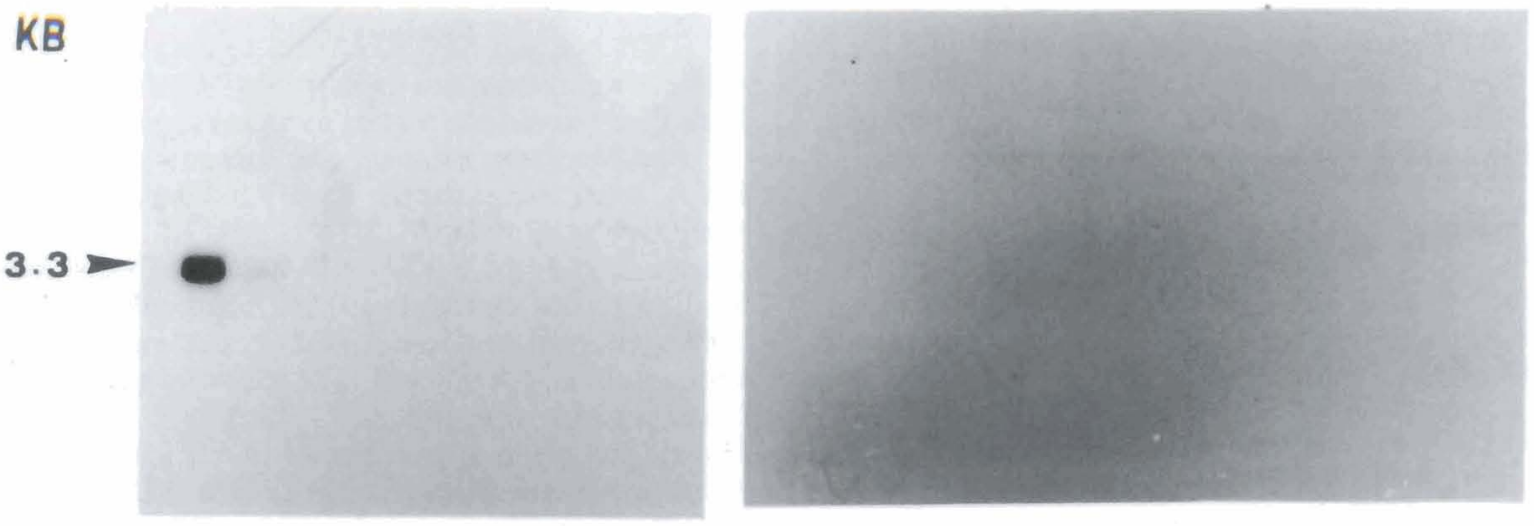

ACTIN
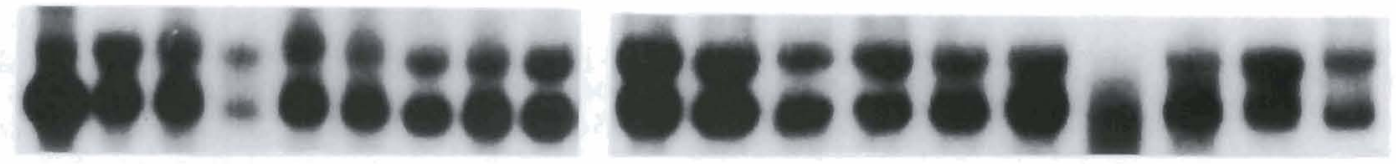

Fig. 1. Northern blot analysis of RNA samples from F9 cells (lane 1), OTT6050 TC (lane 2), 129/Sv STT (lane 3), testis of 2, 5, 10, 14, 25 and 72 days p.c. (lanes 4 to 9) and mouse embryos of 7.5 to 12 days (lanes 10 to 15) and head of 13.5-day and 14.5-day embryos (lanes 16 and 18) and body of 13.5 days and 14.5-day embryos (lanes 17 and 19). $25 \mu \mathrm{g}$ of total RNA are electrophoresed in each line. A $\alpha$ P 32 -UTP-labelled antisense k-FGF riboprobe is used, as described in materials and methods. Film was exposed overnight. The same membrane was reprobed with the antisense human B-actin riboprobe.

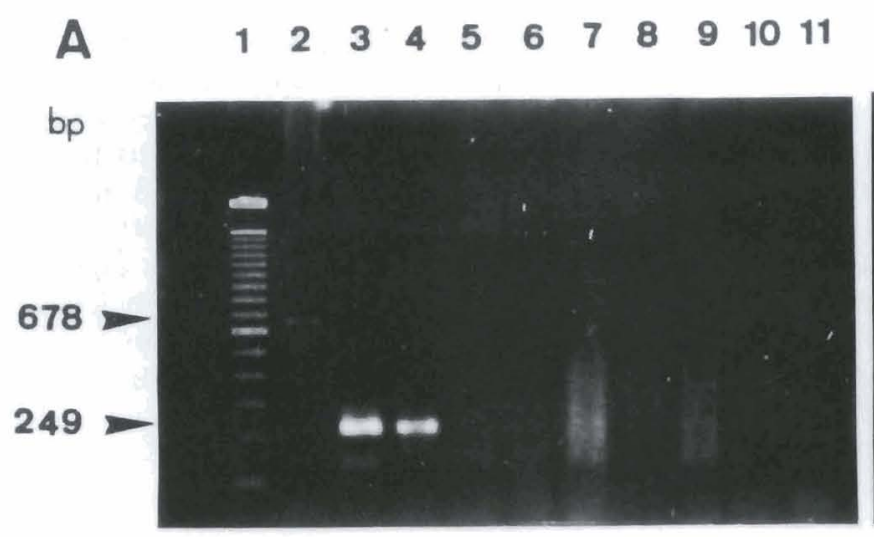

12131415161718192021

B

$\begin{array}{lllllllllll}1 & 2 & 3 & 4 & 5 & 6 & 7 & 8 & 9 & 10 & 11\end{array}$
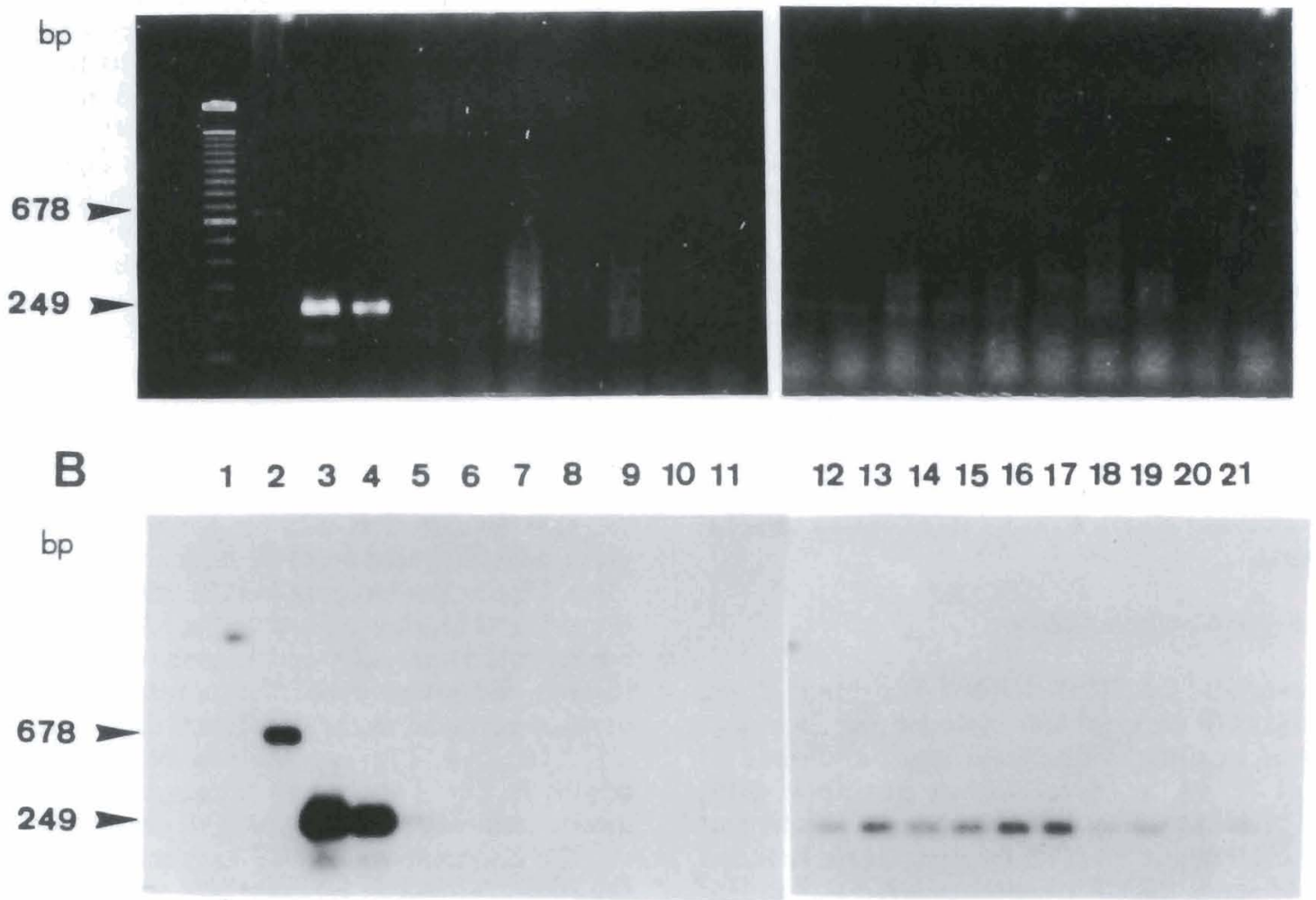

Fig. 2. RT-PCR analysis of k-FGF transcripts. Ethidium bromide-stained agarose gel of reverse transcriptase-polymerase chain reaction (RT-PCR) products (A). 100bp ladder (lane 1), F9 DNA (lane 2), RNA from F9 cells (lane 3), from OTT6050 teratocarcinoma (lane 4), from a spontaneous testicular teratoma (lane 5), from 2, 5, 10, 14, 25 and 72 days p.p. testis (lanes 6 to 11), from 7.5-, 8.5-, 9.5-, 10.5-, 11.5-. 12.5-day mouse embryos (lanes 12 to 17), from heads of 13.5- and 14.5-day embryos (lanes 18 and 20) and from bodies of 13.5- and 14.5-day embryos (lanes 19 and 21). Southern blot of the same gel, using as a probe a $\alpha^{32} \mathrm{P}-\mathrm{dCTP}$-labelled $155 \mathrm{bp}$ Avall fragment (see material and methods) (B). The positions of molecular weight markers are indicated. 
transcript in postimplantation mouse embryos (E7.5 to E12.5 and from head and body of E13.5 to E14.5) on Northern blots under our experimental conditions (Fig. 1).

These results showed that k-FGF mRNA expression was apparently restricted to undifferentiated F9 cells and OTT6050 TC, being undetectable in testis, STT and embryos under our experimental conditions. However, the possibility that expression was restricted to few clumps of cells of the testis and of the STT, which could not be detected by this technique, was not ruled out.

RT-PCR analysis of postnatal testis, a 129/SV STT, OTT6050 TC, F9 cells and embryos

Amplification of RNA-specific sequences via cDNA (RT-PCR) is a powerful and very sensitive method to

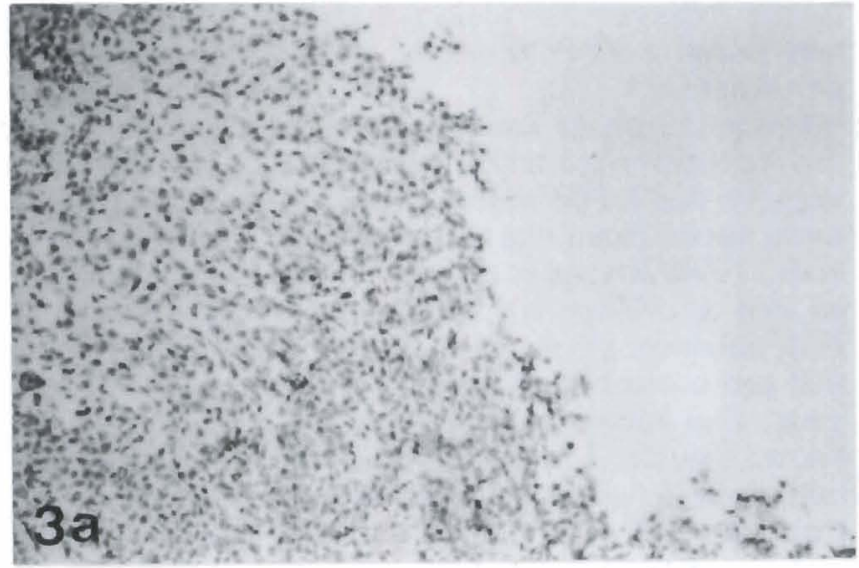

analyze RNA (Kawasaki et al., 1988). Due to the fact that we could not detect k-FGF mRNA in postnatal testis, STT or embryos, we decided to analyze the presence of k-FGF transcripts by RT-PCR. The analysis of the PCR products revealed (Fig. 2) a 249 bp visible band on the agarose gel and a strong signal onto the blot corresponding to the specific primed RNAs in F9 cells and OTT6050 TC. We also detected a clearly visible fragment in postimplantation mouse embryos and only a faint band in the STT on the blot. However, we did not observe appreciable expression in $\mathrm{T} 2$ testis. As a control of k-FGF-specific priming $500 \mathrm{ng}$ of F9 DNA was used, detecting a band of 649 bp as expected (Fig. 2).

\section{In situ hybridization in testis, tumors and embryo sections}

Using testis sections of different postnatal ages (T2,

Fig. 3. Bright field (A) and dark field photograph (B) of OTT6050 TC hybridized with a $\alpha^{32}$ P-UTP-labelled antisense k-FGF riboprobe. Embryonal carcinoma (EC) cells express high amounts of k-FGF transcripts. $x 250$
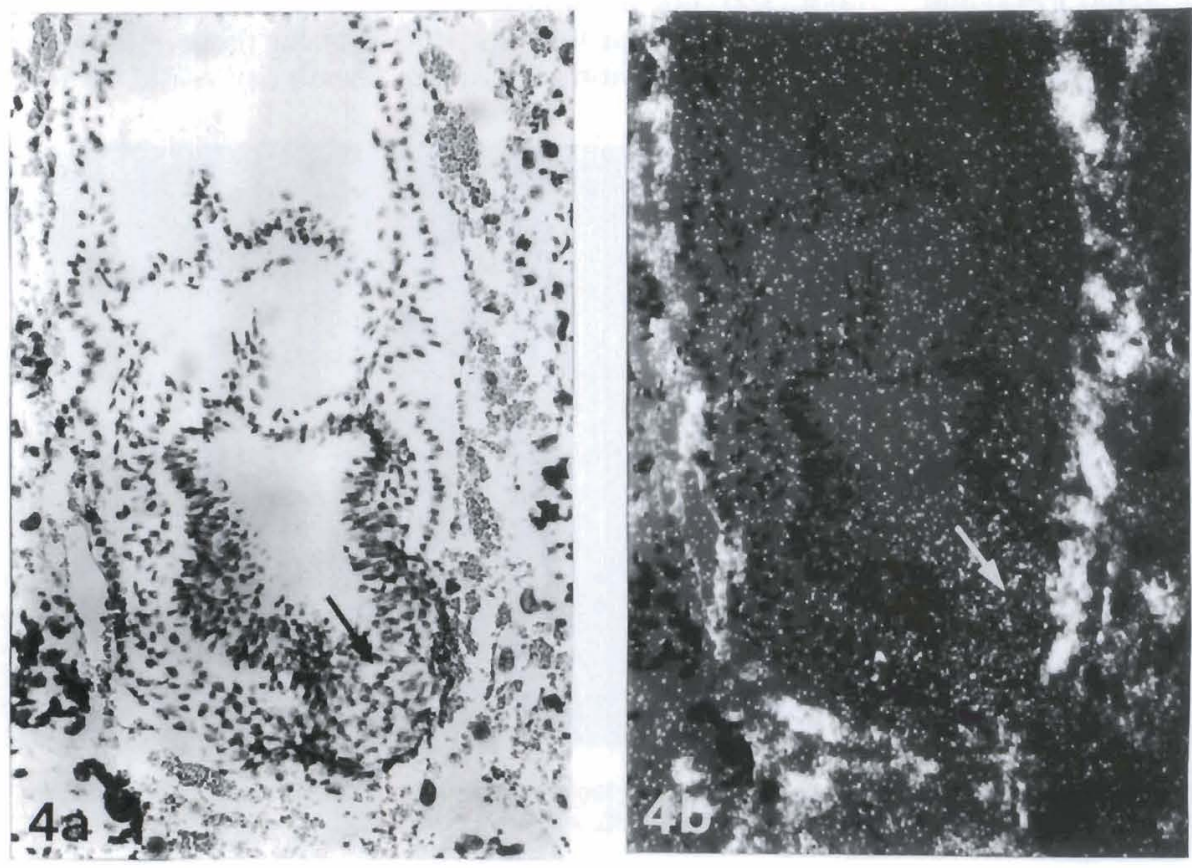

Fig. 4. Bright field (A) and dark field photograph (B) of a 7.5-day mouse embryo hybridized with a $\alpha^{32}$ P-UTP-labelled antisense k-FGF riboprobe. Arrows indicate kFGF transcription in the primitive streak.

$\times 250$

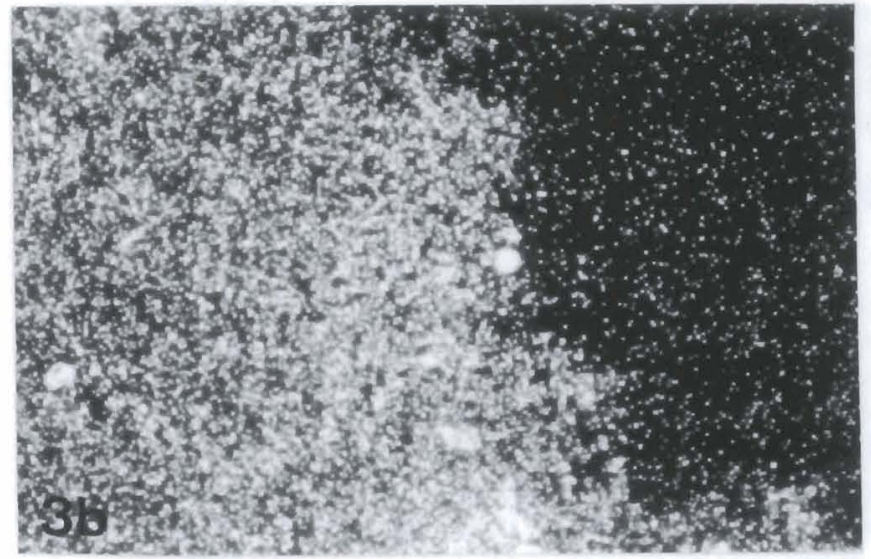




\section{k-FGF expression in testicular development and teratogenesis}

T5, T10, T25, T72) and hybridizing with the antisense $\mathrm{k}$ FGF riboprobe, we could not detect any expression, even after exposing the slides for one month, as expected from the results obtained in RT-PCR experiments (data not shown). On the other hand, in STT sections, where we could not observe the presence of undifferentiated EC cells, we did not detect remarkable k-FGF expression in any differentiated tissue (data not shown). However, and in agreement with the results obtained by RT-PCR, we detected k-FGF expression in EC cells within the OTT6050 TC (Fig. 3), differentiated cells being completely negative. On the other hand, in mouse embryo sections we detected expression in the primitive streak of E7.5 (Fig. 4), but we were unable to detect any specific expression in the developing mouse gonad (Fig. $5)$.

Sections were hybridized with an antisense human B-actin riboprobe, giving a high signal in all the cells (data not shown). All the sections were hybridized with sense $\mathrm{k}-\mathrm{FGF}$ and $\mathrm{B}$-actin riboprobes using the same conditions as antisense probes, and as expected, we did not observe any signal.

\section{Discussion}

The k-FGF gene, as previously reported by Paterno et al. (1989), is a secreted growth factor (GF), member of the fibroblast growth factor family that has been involved to cell proliferation and differentiation during early development. In addition to its role in the normal development, it has been implicated in the tumoral, as mentioned above. Therefore, K-FGF expression has been studied mainly in many tumors and during embryogenesis. However, k-FGF expression has not been studied during testicular development. Testicular germ cells prepared from neonatal ( $48 \mathrm{~h}$ after birth) mice proliferate in vitro (Maekawa and Nishimune, 1991) and there is a high proliferative activity of gonocytes in the pre- (day 14 postcoitum) and early postnatal period (day
2 postpartum) of murine testicular development (Vergouwen et al., 1991), effects with presumably are the consequence of the action of a different GFs. Several GFs play different roles during testicular development. Insulin or IGF-I is required during the initial phase of testicular organization (Taketo et al., 1991) and nerve growth factor-like proteins with mitogenic activity have been isolated from round spermatids and pachytene spermatocytes (Onoda et al., 1991). In particular, a basic fibroblast growth factor has been detected in immature and adult testis (Mayerhofer et al., 1991; Lahr et al., 1992).

Although k-FGF is not expressed in any adult tissue, including adult testis (Yoshida et al., 1988a-c), previous data have shown that a great number of human testicular germ cell tumors express the k-FGF protoncogene (Strohmeyer et al., 1991). However, we have not detected k-FGF expression by Northern blotting (Fig. 1), in situ hybridization (data not shown) or even by the very sensitive RT-PCR method, at any stage of testicular development (Fig. 2). There is not very much information about factors that regulate K-FGF gene during embryogenesis. However, recent evidence suggests that $\mathrm{k}$-FGF expression is regulated by a NK-Y transcription factor that binds to k-FGF promoter (Hasan et al., 1994; Bryans et al., 1995) and several ubiquitous as well as cell-specific octamer factors that bind to kFGF enhancer (Koda et al., 1994). One of the factors that can control its expression is the product of Oct-4 gene, also known as Oct-3 or NF-A3. Although it is known that Oct-4 is expressed in PGC of embryo testis, but not in the sperm of adult testis (Schöler, 1991) and that this factor activates $\mathrm{k}$-FGF transcription in undifferentiated EC and ES cells (Schoorlemmer and Kruijer, 1991), it clearly does not do so in immature male germ cells. The cause of this lack of expression is not clear; one possibility might be that in these cells Oct4 is neither necessary nor sufficient for the regulation of k-FGF expression. The other possibility could be that
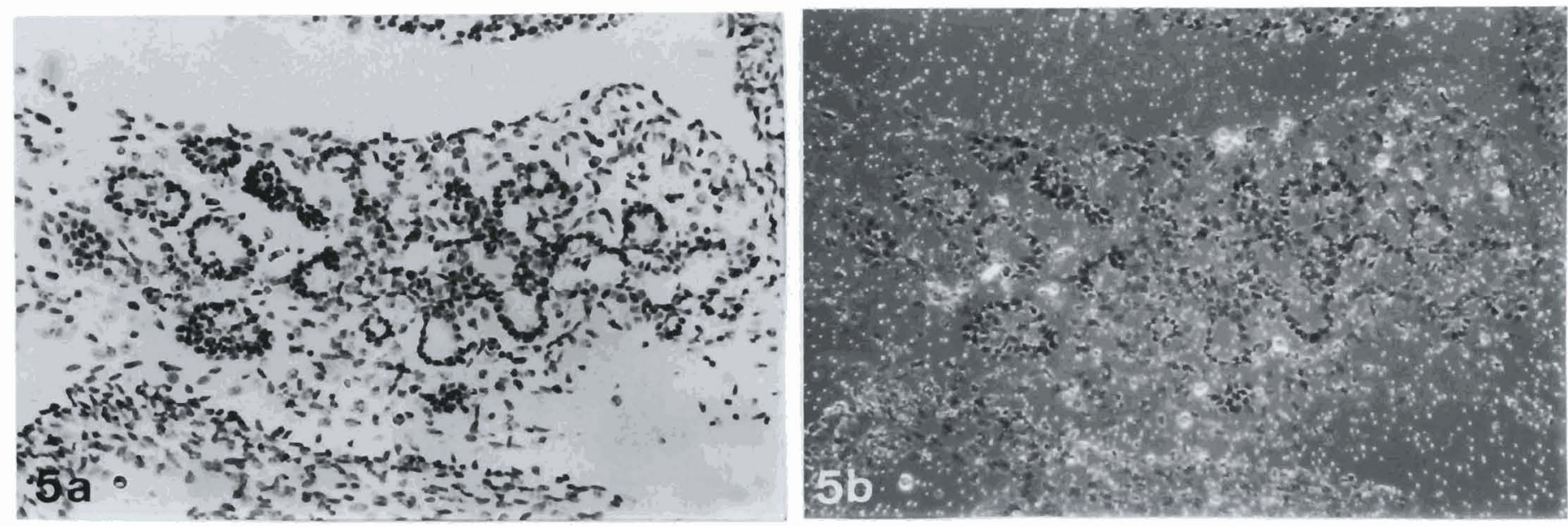

Fig. 5. Bright field (A) and dark field photograph (B) of a 14.5-day mouse embryo developing testis section hybridized with a $\alpha^{32} \mathrm{P}$-UTP-labelled antisense k-FGF riboprobe. Sections were exposed to autoradiographic emulsion for 3 weeks at $4{ }^{\circ} \mathrm{C} . \times 250$ 
after birth, with the appearance of the A spermatogonia and the onset of spermatogenesis, Oct-4 was downregulated, k-FGF transcription not being activated. It should be noted that Oct-4 is a target for negative regulation by retinoic acid (RA) (Okamoto et al., 1990), which in turn mediates its action through RA receptors. Vanbeek and Meistrich (1992) reported the importance of retinoic acid in the maintenance of spermatogenesis. Therefore, it should be of interest to analyze RA and RA receptor expression in mouse testis after birth and in early spermatogenesis (prepubertal stage).

In a spontaneous, $129 / \mathrm{Sv}$ mouse testicular teratoma (STT), we did not detect appreciable k-FGF expression by Northern blotting, although we detected a faint band after blotting the products of the RT-PCR reaction and hybridizing with a specific probe (Fig. 2). This fact indicates that probably only some small groups of undifferentiated cells, which were not included in the analyzed STT sections, express k-FGF, reflecting the conversion to benignancy of the tumor. This clearly associates k-FGF with the degree of undifferentiation of this tumor. Supporting this idea, k-FGF is expressed in primary human testicular tumors (Yoshida et al., 1988ad; Schofield et al., 1991; Strohmeyer et al., 1991).

We used the experimental OTT6050 TC as a positive control for k-FGF expression. We detected expression in the stem cells of the tumor (EC cells), but not in the differentiated tissue by in situ hybridization. The fact that k-FGF is expressed in the stem cells of the tumor and that it is known that this GF acts via an autocrine mechanism (Delli Bovi et al., 1988; Talarico and Basilico, 1991; Moscatelli, 1994), suggest a role of k$\mathrm{FGF}$ in OTT6050 TC in vivo growth.

By Northern blot analysis, we also detected a different level of expression between the nullipotent F9 cell line and the multipotent OTT6050 TC. This result is not surprising and may be explained because OTT6050 TC contained some differentiated cells which are known not to express k-FGF, and also because there are differences in the level of k-FGF expression between several EC cell lines, as previously demonstrated by Schoorlemmer and Kruijer (1991).

In agreement with the results previously reported by Niswander and Martin (1992) indicating k-FGF expression during gastrulation, myogenesis and limb and tooth development, we detected k-FGF transcripts in mouse embryos from E7.5 to E12.5 (Figs. 2, 4) and in the head and body of E13.5 and E14.5 (Fig. 2) by RTPCR. Using an antisense riboprobe for the k-FGF gene, we confirmed some of these results by detecting k-FGF expression in the distal part of the primitive streak of E7.5 (Fig. 4). This zone of the primitive streak contains cells that are fated to become embryonic, but not extraembryonic mesoderm. As discussed by Niswander and Martin (1992), this finding suggests that k-FGF is involved in the specification of some cells within the streak as well as in mesoderm induction in mammals, as demonstrated in amphibia by Paterno et al. (1989). In E7.5, the base of the allantosis, the area where PGC are located, is completely negative, indicating that PGC do not express the k-FGF gene. This result is surprising, because k-FGF is directly transactivated by Oct-4, which is known to be expressed in PGC and in the mouse gonad (Schöler, 1991). However, some evidence suggests that there may be an interaction between Oct-4 and an E1A-like factor. One could speculate that Oct-4 could be complexed by an E1A-like factor, avoiding it binding to the k-FGF enhancer. Indeed, E1 A acts as a bridging factor for transcriptional regulation by Oct-4 (Schöler et al., 1991). Another possibility for this lack of $\mathrm{k}-\mathrm{FGF}$ expression in PGC could be addressed to the presence of a transcriptional repressor. This lack of $\mathrm{k}$ FGF expression in the developing gonad was also maintained in later stages (E12.5, E13.5 and E14.5 mouse embryo sections).

These results indicate that although k-FGF gene is not involved in mouse testicular development, it is involved in mesodermal induction and in the growth of the experimental OTT6050 TC. At the same time, the detection of very low levels of k-FGF transcription in STT, its absence in differentiated cells of STT, as well as its expression in undifferentiated OTT6050 TC cells suggest that the activation of this gene is probably related to the genesis and progression of STT.

Acknowledgements. We gratefully thank Prof. A. Alonso for his helpful technical assistance and Dr. J.K. Heath for providing PXMT2-1.58 kFGF plasmid. We would also like to thank to the Comissió Interdepartamental de Recerca i Innovació Tecnológica (CIRIT). from the Generalitat de Catalunya for financial assistance.

\section{References}

Blin N. and Stafford D.W. (1976). Isolation of high-molecular-weight DNA. Nucleic Acids Res. 3, 2303.

Brookes S., Smith R., Thurlow J., Dickson C. and Peters G. (1989). The mosue homologue of the hst/k-FGF: sequence, genome organization and location relative to int-2. Nucleic Acids Res. 17, 4037-4035

Brustle O., Aguzzi A., Talarico D., Basilico C., Kleihues P. and Wiestler O.D. (1992). Angiogenic acitivity of the K-fgt/hst oncogene in neutral transplants. Oncogene 7, 1177-1183.

Bryans M., Lucas J.M., Knobloch T.J., Wilkie N.M. and Lang J.C. (1995). Regulation of FGF-4 enhancer activity by transcription factor NF-Y. Biochem. Biophys. Res. Commun. 211, 519-527.

Burgess W.H. and Maciag T. (1989). The heparin binding (fibroblast) growth factor family of proteins. Annu. Rev. Biochem. 58, 575-606.

Chikuba K., Saito T., Uchino S., Sato K., Miyahara M., Tsuda H., Hirohashi S. and Kobayashi M. (1995). High amplification of the hst1 gene correlates with haematogenous recurrence after curative resection of oesophageal carcinoma. Br. J. Surg. 82, 364-367.

Curatola A.M. and Basilico C. (1990). Expression fo the K-fgf protooncogene is controlled by 3 ' regulatory elements which are specific for embyronal caricnoma cells. Mol. Cell. Biol. 10, 2475-2484.

Chmozynski P. and Sacchi N. (1987). Single-step method of RNA isolation by acid guanidinium thiocyanate-phenol-chloroform extraction. Anal. Biochem. 162, 156-159. 


\section{k-FGF expression in testicular development and teratogenesis}

Damen J.E., Greenberg A.H. and Wright J.A. (1991). Transformation and amplification of the K-fgf proto-oncogene in $\mathrm{NIH}-3 \mathrm{~T} 3$ cells, and induction of metastatic potential. Biochem. Biophys. Acta 1097, 103110.

Delli Bovi P. and Basilico C. (1987). Isolation of rearranged human transforming gene following transfection of Kaposi sarcoma DNA. Proc. Natl. Acad. Sci. USA 84, 5660-5664.

Delli Bovi P., Curatola A.M., Kern F.G., Greco A., Ittmann M. and Basilico C. (1987). An oncogene isolated by transfection of Kaposi's sarcoma DNA encodes a growth factor that is a member of the FGF family. Cell 50, 729-737.

Delli Bovi P., Curatola A.M., Newman K.M., Sato Y., Moscatelli D., Hewick R.M., Rifkin D.B. and Basilico C. (1988). Processing, secretion and biological properties of a novel growth factor of the fibroblast growth factor family with oncogenic potential. Mol. Cell. Biol. 8, 2933-2941.

Díaz-Flores L., Gutiérrez R. and Varela H. (1994). Angiogenesis: an update. Histol. Histopathol. 9, 807-843.

Feldman B., Poueymirou W., Papaioannou V.E., DeChiara T.M. and Goldbarb M. (1995). Requirement of FGF-4 for postimplantation mouse development. Science 267, 246-249.

Frohman M.A, Boyle M. and Martin G.R. (1990). Isolation of the mouse Hox-2.9 gene: analysis of embyronic expression suggests that positional information along the anterior-posterior axis is specified by mesoderm. Development 110, 589-607.

Hasan S., Koda T. and Kakinuma M. (1994). An upstream NF-Y-binding site is required for transcriptional activation from the hst promoter in F9 embryonal carcinoma cells. J. Biol. Chem. 269, 25042-25048.

Heath J.K., Paterno G.D., Lindon A.C. and Edwards D.R. (1989). Expression of multiple heparin-binding growth factor species by murine embryonal carcinoma and embryonic stem cells. Development 107, 113-122.

Hébert J.M., Basilico C., Goldfarb M., Haub O. and Martin G.R. (1990). Isolation of cDNAs encoding four mouse FGF family members and characterization of their expression patterns during embyrogenesis. Dev. Biol. 138, 454-463.

Jernvall J., Kettunen P., Karavanova I., Martin L.B. and Thesleff I. (1994). Evidence for the role of the enamel knot as a control center in mammalian tooth cusp formation: non-dividing cells express growth stimulating Fgf-4 gene. Int. J. Dev. Biol. 38, 463-489.

Kawasaki E.S., Clark S.S., Coyne M.Y., Smith S.D., Champlin R., Witte O.N. and McCormick F.P. (1988). Diagnosis of chronic myeloid and acute lymphocytic leukemias by detection of leukemia-specific mRNA sequences amplified in vitro. Proc. Natl. Acad. Sci. USA 85 , 5698-5702

Kluin Ph.M. and de Rooij D.G. (1981). A comparison between the morphology and cell kinetics of gonocytes and adult type undifferentiated spermatogonia in the mouse. Int. J. Androl. 4, 475493.

Kluin Ph.M., Kreamer M.F. and de Rooij D.G. (1984). Proliferation of spermatogonia and Sertoli cells in maturing mice. Anat. Embryol. $169,73-78$.

Koda T., Hasan S., Sasaki A., Arimura Y. and Kakinuma M. (1994). Regulatory sequences required for hst-1 expression in embryonal carcinoma cells. FEBS Lett. 342, 71-75.

Lahr G., Mayerhoffer A., Seidl K., Bucher S., Grothe C., Knöchel W. and Gratzl M. (1992). Basic fibroblast growth factor in rodent testis. presence of bFGF mRNA and of a $30 \mathrm{kDA}$ bFGF protein in pachytene spermatocytes. FEBS Lett. 302, 43-46.
Maekawa M. and Nishimune Y. (1991). In-vitro proliferation of germ cells and supporting cells in the neonatal mouse testis. Cell Tissue Res. 265, 551-554.

Mayerhofer A., Russell L.D., Grothe C., Rudolf M. and Gratzl M. (1991). presence and localization of a $30-\mathrm{kDa}$ basic fibroblast growth factorlike protein in rodents testes. Endocrinology 129, 921-924.

McLeskey S.W., Kurebayashi J., Honig S.F., Zwiebel J., Lippman M.E., Dickson R.B. and Kern F.G. (1993). Fibroblast growth factor 4 transfection of MCF-7 cells produces cell lines that are tumorigenic and metastatic in ovariectomized or tamoxifen-treated athymic nude mice. Cancer Res. 53, 2168-2177.

Miyagawa K., Sakamoto H., Yoshida T., Yamashita Y., Mitsui Y. Furusawa M., Maeda S., Takaku F., SugimuraT. and Terada M. (1988). hst-1 transforming protein: expression in silkworm cells and characterization as a novel heparin-binding growth factor. Oncogene 3, 383-389

Moscatelli D. (1994). Autocrine downregulation of fibroblast growth factor receptors in F9 teratocarcinoma cells. J. Cell. Physiol. 160, 555-562.

Murakami A., Tanaka H. and Matsuzawa A. (1990). Association of hst gene expression with metastatic phenotype in mouse mammary tumors. Cell Growth Differ. 1, 225-231.

Niswander L. and Martin G.R. (1992). Fgf-4 expression during gastrulation, myogenesis, limb and tooth development in the mouse. Development 114, 755-768.

Niswander L., Tickle C., Vogel A., Booth I. and Martin G.R. (1993). FGF4 replaces the apical ectodermal ridge and directs outgrowth and patterning of the limb. Cell 75, 579-587.

Niswander L., Tickle C., Vogel A. and Martin G.R. (1994). Function of FGF-4 in limb development. Mol. Reprod. Dev. 39, 83-89.

Okamoto K., Okazawa H., Okuda A., Sakai M., Muramatsu M. and Hamada H. (1990). A novel octamer binding transcription factor is differentially expressed in mouse embyronic cells. Cell 60, 461-472.

Onoda M., Pflug B. and Djakiew D. (1991). Germ cell mitogenic activity is associated with nerve growth factor-like protein(s). J. Cell Physiol. 149, 536-543.

Paterno G.D., Gillespie L.L., Dixon M., Slack J.M.W. and Heath J.K. (1989). Mesoderm-inducing properties of Int-2 and kFGF: two oncogene encoded growth factors related to FGF. Development $106,79-84$

Rappolee D.A., Basilico C., Patel Y. and Werb Z. (1994). Expression and function of FGF-4 in peri-implantation development in mouse embryos. Development 120, 2259-2269.

Sakamoto H., Mori M., Taira M., Yoshida T., Matsukawa S., Shimizu K., Sekiguchi M., Terada M. and Sugimura T. (1986). Transforming gene from human stomach cancers and a noncancerous portion of stomach mucosa. Proc. Natl. Acad. Sci. USA 83, 3997. 4001

Sasaki A., Kubo M., Hasan S., Yano Y. and Kakinuma M. (1991) Regulation of human hst expression by an enhancer element residing in the third exon. Jpn. J. Cancer Res. 82, 1191-1195.

Schofield P.N., Ekström T.J., Granerus M. and Engström W. (1991). Differentiation associated modulation of K-FGF expression in a human teratocarcinoma cell line and in primary germ cell tumours. FEBS Lett. 280, 8-10.

Schöler H.R. (1991). Octamania: The POU factors in murine development. TIG 7, 323-329.

Schöler H.R., Hatzopoulos A.K., Balling R., Suzuki N. and Gruss P. (1989). A family of octamer-specific proteins present during mouse 
embryogenesis: evidence for germline-specific expression of an Oct factor. EMBO J. 8, 2543-2550.

Schöler H.R., Ciesiolka T. and Gruss P. (1991). A nexus between Oct-4 and E1A: implications for gene regulation in embryonic stem cells. Cell 66, 291-304.

Schoorlemmer J. and Kruijer W. (1991). Octamer-dependent regulation of the kFGF gene in embyronal carcinoma and embryonic stem cells. Mech. Dev. 36, 75-86.

Stevens L.C. (1970). The development of transplantable teratocarcinomas from intratesticular grafts of pre- and postimplantation mouse embryos. Dev. Biol. 21, 364-382.

Strohmeyer T., Peter S., Hartmann M., Munemitsu S., Ackermann R., Ullrich A. and Slamon D.J. (1991). Expression of the hst-1 and c-kit protooncogenes in human testicular germ cell tumors. Cancer Res. 51, 1811-1816.

Taketo T., Saeed J., Roberge S., Matsuo N. and Koide S. (1991). Regulation of testicular differentiation and testosterone production in the fetal mouse gonad in vitro. J. Steroid Biochem. Mol. Biol. 38 , 523-531.

Talarico D. and Basilico C. (1991). The K-fgf/hst oncogene induces transformation through an autocrine mechanism that requires extracellular stimulation of the mitogenic pathway. Mol. Cell. Biol. 11, 1138-1145.

Taylor W.R., Greenberg A.H., Turley E.A. and Wright J.A. (1993). Cell motility, invasion, and malignancy induced by overexpression of $\mathrm{K}$ FGF or bFGF. Exp. Cell Res. 204, 295-301.

Tronick S.R. and Aaronson S.A. (1995). Growth factors and signal transduction. In: The molecular basis of cancer. Mendelson J., Howley S., Israel C. and Liotta L.A. (ed). W.B. Saunders Company. Philadelphia, London, Toronto, Montreal, Sidney, Tokyo. pp 117-142.

Vanbeek M.E.A.B. and Meistrich M.L. (1992). Spermatogenesis in retinol-deficient rats maintained on retinoic acid. J. Reprod. Fert. 94, 327-336.

Velcich A., Delli Bovi P., Mansukhani A., Ziff E.B. and Basilico C. (1989). Expression of the K-fgf protonocgene is repressed during differentiaiton of F9 cells. Oncogene Res. 5, 31-37.

Vergouwen R.P.F.A., Jacobs S.G.P.M., Huiskamp R., Davids J.A.G. and de Rooij D.G. (1991). Proliferative activity of gonocytes, sertoli cells and interstitial cells during testicular development in mice. J. Reprod. Fert. 93, 233-243.

Vogel A. and Tickle C. (1993). FGF-4 maintains polarizing activity of posterior limb bud cells in vivo and in vitro. Development 119, 199206.

Volling P., Jungehulsing M., Jucker M., Stutzer H., Diehl V. and Tesch H. (1993). Coamplification of the hst and bcl-1 oncogenes in advanced squamous cell carcinomas of the head and neck. Eur. J. Cancer 29A, 383-389.

Yoshida T., Miyagawa K., Odagiri H., Sakamoto H., Little P., Terada M. and Sugimura T. (1987). Genomic sequence of hst, a transforming gene encoding a protein homologous to fibroblast growth factors and the int-2-encoded protein. Proc. Natl. Acad. Sci. USA 84, 73057309.

Yoshida T., Tsutsumi M., Sakamoto H., Miyagawa K., Teshima S., Sugimura T. and Terada (1988a). Expression of HST1 oncogene in human germ cell tumors. Biochem. Biophys. Res. Commun. 155, 1324-1329.

Yoshida T., Muramatsu H., Muramatsu T., Sakamoto H., Katoh O., Sugimura T. and Terada (1988b). Differential expression of two homologous and clustered oncogenes, hst1 and int2, during differentiation of F9 cells. Biochem. Biophys. Res. Commun. 157, 618-625.

Yoshida M.C., Wada M., Satoh H., Yoshida T., Sakamoto H., Miyagawa K., Yokota J., Koda T., Kakinuma M., Sugimura T. and Terada M. (1988c). Human HST1 (HSTF1) gene maps to chromosome band $11 \mathrm{q} 13$ and coamplifies with the INT2 gene in human cancer. Proc. Natl. Acad. Sci. USA 85, 4861-4864.

Yoshida T., Ishimaru K., Sakamoto H., Yokota J., Hirohashi S., Igarashi K. and Sudo K. (19894). Angiogenic activity of the recombinant hst-1 protein. Cancer Lett. 83, 261-268.

Accepted June 9, 1996 